\title{
MENINGKATKAN KESADARAN GENERASI MUDA UNTUK BERPERILAKU ANTI KORUPTIF MELALUI PENDIDIKAN ANTI KORUPSI
}

\author{
I Gusti Agung Ayu Dike Widhiyaastuti \\ I Gusti Ketut Ariawan \\ Bagian Hukum Pidana Fakultas Hukum Universitas Udayana \\ dikewidhiyaastuti@gmail.com ;_ariawanigk@yahoo.com
}

\begin{abstract}
Abstrak
Artikel ini berjudul Meningkatkan Kesadaran Generasi Muda Untuk Berperilaku Anti Koruptif melalui Pendidikan Anti Korupsi yang didasarkan pada hasil penelitian tentang Kesadaran Hukum Mahasiswa Fakultas Hukum Universitas Udayana dalam Mengembangkan Perilaku Anti Koruptif pada tahun 2016. Secara garis besar, masalah yang ingin dibahas adalah kesadaran generasi muda akan perannya sebagai agent of change bagi persoalan korupsi di Indonesia dan peran penting pendidikan anti korupsi dalam menumbuhkan kesadaran hukum generasi muda. Metode yang dipergunakan dalam penelitian tersebut adalah metode empiris dengan menggunakan pendekatan fakta dan pendekatan konsep serta disajikan secara deskriptif analitis. Hasil yang diperoleh dalam penelitian tersebut adalah generasi muda memiliki cukup pengetahuan tentang korupsi, bentuk-bentuk korupsi serta bentuk-bentuk perilaku anti koruptif. Hanya saja pengetahuan yang cukup itu belum diikuti oleh kehendak untuk berperilaku anti koruptif. Ini artinya ada kelemahan dalam diri generasi muda terkait kesadaran untuk mengembangkan budaya anti koruptif dalam dirinya sehingga dapat disimpulkan bahwa perlu diadakan pendidikan anti korupsi bagi generasi muda agar dapat membantu menumbuhkan kesadaran hukum mereka untuk berperilaku anti koruptif.
\end{abstract}

Kata Kunci : Meningkatkan, Kesadaran, Perilaku Anti Koruptif, Generasi Muda, Pendidikan

\begin{abstract}
The title of this article is Increase the Young Generation Legal Awareness to Developing Anti Corruption Behavior Through Anti Corruption Education which is basically based on research about The Student of Faculty of Law Legal Awareness to Developing Anti Corruption Behavior in 2016. In general, the article discuss the problems of young generation knowledge about corruption, the corruption forms and anti corruption forms also about the young generation legal awareness to developing the anti corruption behavior. The empiric methods with the factual and concept approach use to solve those problems and describe in analytic description. The result of the research is young generation have a good knowledge about corruption, the forms of corruption and the forms of anti corruption from the simplest to the harder but this good knowledge did not followed by their legal awareness to developing anti corruption behavior. It means there is a weakness in the young generation mentally to developing anti corruption behavior. This situation describing the needed of anti corruption education for the young generation. Hopefully through the education will increase the young generation legal awareness to developing anti corruption behavior.
\end{abstract}

Keywords: increase, awareness, anti corruption behavior, young generation, education

\section{PENDAHULUAN}

\subsection{Latar Belakang}

Indonesia dan korupsi memberi kesan tentang dua hal yang tidak dapat dipisahkan. Indonesia begitu identik dengan persoalan korupsi dan korupsi juga begitu identik dengan Indonesia. Hal ini tidak dapat dipungkiri mengingat kasus korupsi di Indonesia yang begitu banyak dan terkesan patah hilang tumbuh berganti. Hampir setiap saat selalu bermunculan kasus korupsi baru dengan pemain baru ataupun pemain lama sehingga menimbulkan kesan bahwa Indonesia sangat sarat dengan korupsi dan korupsi seperti budaya yang hidup dalam masyarakat Indonesia.

Persoalan korupsi di Indonesia yang tiada henti ini memang sangat memprihatinkan. Korupsi nampak bagaikan penyakit yang menggerogoti mental manusia Indonesia yang sulit untuk diobati. Bahkan jargon-jargon anti 
korupsi yang seringkali dijumpai dijalanjalan ataupun dilembaga-lembaga tertentu terkesan hanya bagaikan omong kosong yang tak berfaedah, tanpa makna hanya kata-kata kosong yang membosankan. Kondisi ini tidak jarang diperparah dengan pembiaran-pembiaran yang kerap dilakukan oleh masyarakat Indonesia baik itu disengaja ataupun tidak disengaja. Pembiaran-pembiaran sebagaimana dimaksud adalah serangkaian tindakan yang dianggap biasa dan wajar dilakukan dalam upaya memperoleh keuntungan baik untuk diri pribadi maupun untuk orang lain.

Hal tersebut juga menjadi sebab mengapa korupsi begitu sulit dicegah dan diberantas. Korupsi telah menjadi perilaku dalam keseharian masyarakat dan telah tumbuh menjadi suatu kebiasaan, suatu budaya. Sebuah jurnal asing sebagaimana yang dikutip oleh Amien Rais menggambarkan bahwa "corruption is way of life in Indonesia", yang berarti korupsi telah menjadi pandangan dan jalan kehidupan bangsa Indonesia. ${ }^{1}$ Bahkan jauh sebelum jurnal asing tersebut menggambarkan kondisi korupsi di Indonesia, Muhammad Hatta salah seorang tokoh proklamator kemerdekaan Indonesia pernah melontarkan penilaian dengan mengatakan bahwa korupsi cenderung sudah membudaya, atau sudah menjadi bagian dari kebudayaan bangsa Indonesia. $^{2}$ Ini artinya korupsi di Indonesia telah dianggap dan dipandang begitu masiv sehingga memasuki ranah mental dan budaya masyarakat Indonesia dan menjadi sulit untuk dicegah serta diberantas.

Sebagaimana diketahui, pencegahan dan pemberantasan korupsi di Indonesia telah dilakukan sejak tahun 1999 dengan

${ }^{1}$ Amien Rais, Pengantar dalam Edi Suandi Hamid dan Muhammad Sayuti (ed), Menyikapi Korupsi, Kolusi dan Nepotisme di Indonesia, Aditya Media, Yogyakarta dalam Elwi Danil, sebagaimana dikutip oleh I Gst Agung Ayu Dike Widhiyaastuti dkk, 2016, Klinik Hukum Anti Korupsi Edukasi Pencegahan Melalui Street Law, Udayana University Press, Denpasar, hal. 23 Ibid.

${ }^{2}$ I Gst Agung Ayu Dike Widhiyaastuti dkk, diterbitkannya UU No. 31 Tahun 1999 jo UU No. 20 Tahun 2001 tentang Tindak Pidana Korupsi. Dengan demikian pada prinsipnya pencegahan dan pemberantasan korupsi telah menjadi komitmen bangsa Indonesia. Komitmen ini ditunjukkan dengan penyelenggaraan pemberantasan tindak pidana korupsi secara represif dengan menegakkan UU Tindak Pidana Korupsi serta dengan membentuk suatu lembaga yang secara khusus diadakan untuk mencegah dan memberantas korupsi yaitu Komisi Pemberantasan Korupsi atau KPK.

Memperhatikan pola sistem pemberantasan korupsi di Indonesia dapat dikatakan bahwa telah ada upayaupaya substantive dan struktural dalam pencegahan dan pemberantasan korupsi melalui pembentukan undang-undang dan lembaga anti korupsi. Kedua upaya substantive dan struktural tersebut merupakan upaya penegakan hukum pidana dengan menggunakan sarana penal untuk menanggulangi suatu kejahatan.

Dalam konteks penanggulangan kejahatan, upaya penal dapat dilengkapi dengan upaya non penal yang bersifat preventif yang jika diletakkan dalam pola sistem maka upaya non penal ini adalah bagian dari budaya. Upaya preventif dalam penanggulangan korupsi dapat diwujudkan dengan melakukan tindakantindakan yang sifatnya pencegahan terjadinya tindak pidana korupsi. Berbicara tentang pencegahan korupsi sebetulnya sudah ada program-program yang mengkampanyekan anti korupsi namun masih terkesan belum maksimal. Contohnya, upaya membudayakan anti korupsi melalui program kantin anti korupsi yang dulu pernah dikembangkan ke sekolah-sekolah dari semua tingkatan baik itu SD, SMP, SMA maupun perguruan tinggi saat ini sudah tidak pernah lagi terdengar dengungnya. Hal ini mengindikasikan belum suksesnya upaya membudayakan perilaku anti koruptif ke tengah-tengah masyarakat terutama kepada generasi mudanya.

Sebagaimana umum diketahui, generasi muda merupakan harapan bagi 
suatu bangsa untuk di masa yang akan datang. Generasi muda merupakan tonggak terlaksananya perubahanperubahan dalam suatu bangsa. Dalam bidang korupsi, generasi muda juga memiliki peran yang amat penting. Generasi muda dengan segala idealismenya dapat memutus mata rantai korupsi jika sejak dini telah dibekali dengan mental anti koruptif yang dapat diperoleh melalui pendidikan anti korupsi.

\subsection{Rumusan Masalah}

Berdasarkan latar belakang tersebut diatas, dapat dirumuskan beberapa permasalahan :

1. Bagaimanakah kesadaran hukum generasi muda saat ini akan perannya sebagai agent of change bagi masalah korupsi di Indonesia?

2. bagaimanakah arti penting pendidikan anti korupsi dalam meningkatkan kesadaran hukum generasi muda dalam menumbuhkan perilaku anti koruptif?

\subsection{Tujuan Penelitian}

Penelitian ini bertujuan untuk mengetahui kesadaran hukum generasi muda saat ini akan perannya sebagai agent of change bagi masalah korupsi di Indonesia dan untuk mengetahui arti penting pendidikan anti korupsi dalam meningkatkan kesadaran hukum generasi muda dalam menumbuhkan perilaku anti korupsi.

\subsection{Metode Penelitian}

Metode yang dipergunakan dalam penelitian ini adalah metode penelitian empiris dengan menggunakan pendekatan faktual dan konsep berkaitan dengan kesadaran hukum generasi muda dalam menumbuhkan perilaku anti koruptif dan pentingnya pendidikan anti korupsi dalam meningkatkan kesadaran hukum mahasiswa dalam menumbuhkan perilaku anti koruptif.

\section{PEMBAHASAN}

\subsection{Masalah Korupsi di Indonesia}

Korupsi telah menjadi permasalahan yang sangat krusial bagi bangsa Indonesia. Korupsi telah menjamur ke berbagai aspek bidang kehidupan sehingga menimbulkan banyak kerugian yang sifatnya materiil maupun immateriil. Secara materiil, terjadi kerugian pada keuangan negara sedangkan secara immateriil terjadi kerugian pada moralitas dan mental bangsa Indonesia yang pada akhirnya akan sulit untuk dibenahi.

Berdasarkan penelusuran dalam berbagai media dapat diketahui bahwa korupsi di Indonesia pada dasarnya telah terjadi sejak jamannya para raja yang kemudian berlanjut ke jaman penjajahan Belanda. Seorang sejarahwan UGM Suhartono menggambarkan hal ini dalam dalam Seminar Hasil Penelitian Lintas Klaster Humaniora juga menguraikan bagaimana korupsi di Indonesia telah terangkai sejak jaman feodalisme. Suhartono menyebutkan bahwa birokrasi tradisional yang terbentuk pada jaman feodalisme merupakan benih awal terbentuknya mental korupsi. Disamping menyebutkan bahwa kronologis korupsi di Indonesia disebabkan karena struktur masyarakat yang ada, keberlangsungan secara sosio kultural yang menurutnya hampir tidak mengalami perubahan signifikan sehingga korupsi tetap berlangsung selama puluhan abad. ${ }^{3}$ Dalam konteks ini, Suhartono menggarisbawahi kebiasaan permisif, tanpa pengawasan dan kontrol terhadap perilaku koruptif yang dikembangkan oleh masyarakat Indonesia sejak dahulu kala hingga saat ini telah menjadi suatu boomerang bagi bangsa Indonesia. ${ }^{4}$

Theodore M Smith sebagaimana dikutip dalam Mochtar Lubis dan James Scott juga memberikan tambahan tentang bagaimana korupsi berlangsung di Indonesia. ${ }^{5}$ Theodore M Smith menganalisa bahwa sebagian besar permasalahan korupsi di Indonesia

$$
{ }^{3} \text { Suhartono }
$$

dalam

https://ugm.ac.id/id/berita/433-

sejarawan.ugm.korupsi.warisan.dari.penyakit.sosi al.orang.indonesia diunggah tanggal 26 Agustus 2017

${ }^{4}$ Ibid.

${ }^{5}$ Theodore M Smith dikutip dalam Mochtar Lubis dan James Scott oleh http://sejarah.kompasiana.com/2012/06/22/korups i-birokrasi-sebuah-warisan-kolonial-471739.html , diunggah tanggal 26 Agustus 2017 
disebabkan karena faktor kultural, ekonomi dan politik. Ia juga menegaskan bahwa faktor sejarah yang ditunjukkan dengan adanya watak feodalisme bangsa Indonesia menjadi faktor utama penyebab maraknya korupsi di Indonesia. Analisanya tersebut diilanjutkan dengan menyebutkan faktor-faktor lain seperti faktor kebudayaan yang merupakan implikasi negative sistem feodalisme, faktor ekonomi yang ditunjukkan dengan rendahnya kesejahteraan di Indonesia, faktor struktur pemerintahan yang masih sentralistik dan faktor politik yang kotor oleh karena kepentingan dana bagi partaipartai yang ingin memenangkan pemilu menjadi penyebab kian maraknya korupsi di Indonesia.

Wertheim juga menyoroti faktor budaya sebagai penumbuh suburnya korupsi di Asia Tenggara termasuk didalamnya Indonesia. $^{6}$ Wertheim menyebutkan bahwa hubungan patrimonial dalam budaya masyarakat sebagai suatu potensi terjadinya korupsi. Ia menerangkan bahwa sikap loyalitas terhadap kerabat seringkali jauh lebih menonjol dibandingkan loyalitas kepada masyarakat. Hal ini seringkali menimbulkan keadaan dimana seseorang yang menduduki jabatan strategis lebih mengutamakan kerabatnya dan melakukan penyalahgunaan wewenang untuk kepentingan kerabatnya tersebut. Kebiasaan tersebut terwarisi hingga saat ini dan masih meracuni birokrasi modern yang terus menumbuhsuburkan korupsi melalui perilaku nepotisme, yang pada akhirnya mempunyai potensi yang besar bagi terjadi dan berkembang biaknya korupsi. $^{7}$

Berdasarkan uraian-uraian tersebut dapat diketahui bahwa korupsi di Indonesia pada dasarnya merupakan suatu fenomena yang telah berlangsung selama beberapa abad dan menjadi

\footnotetext{
${ }^{6}$ Wertheim dalam Muchtar Lubis dan James C Scott, 1995, Bunga Rampai Korupsi sebagaimana dikutip oleh Elwi Danil, 2014, Korupsi: Konsep, Tindak Pidana dan Pemberantasannya, PT. RajaGrafindo Persada, Jakarta, Hal. 51

${ }^{7}$ Ibid.
}

persoalan yang amat sulit untuk ditanggulangi. Sulitnya penanggulangan korupsi ini ditengarai karena korupsi telah menjadi suatu budaya, suatu kebiasaan, suatu "way of life" sebagaimana dikemukakan sebuah jurnal asing yang dikutip oleh Amien Rais.

Korupsi pada prinsipnya merupakan perbuatan yang secara umum dilakukan dengan tujuan untuk memperoleh keuntungan. Dalam upaya memperoleh keuntungan inilah cenderung dipergunakan cara-cara yang kurang baik, misalnya dengan melakukan penyuapan, pemerasan, gratifikasi dan lain sebagainya. Apabila merujuk pada ketentuan dalam UU No. 31 Tahun 1999 jo. UU No. 20 Tahun 2001 tentang Tindak Pidana Korupsi ada beberapa jenis perbuatan yang dapat dikategorikan sebagai perbuatan korupsi yang dapat dipidana yaitu:

a. Korupsi yang mensyaratkan adanya kerugian negara atau perekonomian negara;

b. Penyuapan;

c. Penyalahgunaan jabatan;

d. Pemerasan;

e. Kecurangan;

f. Korupsi berkaitan dengan pengadaan barang dan jasa

g. Gratifikasi

h. Percobaan, permufakatan jahat dan pembantuan tindak pidana korupsi

i. Dan beberapa jenis perbuatan yang berkaitan dengan tindak pidana korupsi

Di Indonesia, perbuatan-perbuatan korupsi sebagaimana tersebut diatas sudah umum dilakukan. Menurut data statistic KPK, penyuapan merupakan jenis perbuatan korupsi yang paling banyak dijumpai. Dilanjutkan kemudian dengan korupsi pengadaan barang dan jasa menempati posisi kedua terbanyak dan posisi ketiga ditempati oleh perbuatan penyalahgunaan anggaran. ${ }^{9}$ Untuk wilayah tertinggi terjadi korupsi ada di pemerintahan pusat, disusul DKI

${ }^{8}$ Ibid., hal.65

${ }^{9}$ https://acch.kpk.go.id/id/statistik/tindakpidana-korupsi/tpk-berdasarkan-jenis-perkara di unggah tanggal 26 Agustus 2016 
Jakarta, Jawa Barat, Jawa Timur dan Sumatera Utara.

Mengenai instansi terkorup, data KPK memberikan gambaran tertinggi pada instansi kementerian/lembaga dengan jumlah kasus sebanyak 274 kasus, diikuti dengan instansi Pemkab/Pemkot dengan jumlah kasus sebanyak 181 kasus serta instansi pemerintah pemerintah propinsi dengan jumlah kasus 99 kasus dan posisi instansi terakhir yang terkorup adalah DPR/DPRD dengan 61 kasus. $^{10}$

Untuk profesi dan jabatan yang paling korup, data KPK menunjukkan bahwa sebanyak 184 kasus dilakukan oleh mereka yang memiliki profesi dan jabatan swasta. Diikuti oleh profesi pada Eselon I/II/dan III yang berjumlah sebanyak 175 kasus. Di posisi ketiga profesi dan jabatan terkorup ternyata diduduki oleh DPR/DPRD dengan jumlah 145 kasus, sedang untuk profesi dan jabatan Hakim dapat dikategorikan rendah dilihat dari sepanjang tahun 2004 hingga tahun 2017 terdapat hanya 17 kasus yang melibatkan hakim pada tindak pidana korupsi. Demikian pula halnya dengan profesi dan jabatan jaksa, polisi serta pengacara yang sepanjang tahun 2004 sampai tahun 2017, jaksa yang terlibat korupsi ada sebanyak 7 kasus, polisi 2 kasus dan pengacara 6 kasus. ${ }^{11}$

Di sepanjang tahun 2004 sampai tahun 2017, ditemukan 1 kasus tindak pidana korupsi yang melibatkan korporasi. Hal ini dapat dimaklumi mengingat, korporasi dalam prinsip hukum pidana bukanlah merupakan subyek hukum pidana namun dalam perkembangannya korporasi dapat menjadi subyek hukum pidana.

Melihat data statistik yang dikeluarkan KPK tersebut dapat diketahui bahwa masalah korupsi di Indonesia saat ini kian memprihatinkan. Jumlah korupsi dari tahun ke tahun tidak juga mengalami penurunan melainkan justru mengalami banyak peningkatan dengan semakin banyaknya pelaku-pelaku korupsi yang ditangkap untuk diproses secara hukum. Hal ini seakan menggambarkan bahwa korupsi bukanlah perbuatan hukum yang bersifat melawan hukum dan dilarang untuk dilakukan serta dapat menimbulkan akibat pada diri sendiri dan juga masyarakat luas.

Di samping semakin banyaknya tindak pidana korupsi yang dilakukan, perkembangan lain juga terlihat dalam hal pelaku korupsi. Dari data yang dikeluarkan KPK terlihat bahwa pelaku korupsi terbanyak ada pada profesi swasta. Ini memberikan deskripsi bahwa ada perkembangan tentang pelaku korupsi yang tidak hanya para birokrat sebagaimana sudah dikembangkan oleh beberapa pemikiran melainkan mulai mengarah pada profesi swasta. Korupsi yang dilakukan oleh mereka yang berprofesi swasta umumnya berkaitan dengan penyuapan, penyalahgunaan wewenang dan juga berkaitan dengan persoalan pengadaan barang dan jasa. Celah korupsi oleh profesi swasta umumnya ada pada saat melakukan kerjasama dengan birokrat berkaitan dengan ijin, tender pengerjaan proyek padat karya dan lain sebagainya.

Mengenai korupsi birokrasi, data yang ditunjukkan statistik KPK menggambarkan bahwa birokrasi tetap rentan dengan korupsi. Kapan saja, dimana saja dan siapa saja yang berprofesi birokrat dalam instansi seperti kementerian, pemkot/pemkab memiliki kemungkinan-kemungkinan untuk terlibat dalam tindak pidana korupsi.

Dengan demikian, masalah korupsi di Indonesia sesungguhnya tidak dapat dipandang dengan sebelah mata. Masalah korupsi yang dikatakan merajalela di Indonesia merupakan pernyataan yang tepat. Data KPK menunjukkan bahwa kasus tindak pidana korupsi di Indonesia sangat fluktuaktif dan cenderung tetap selalu ada dalam setiap tahunnya. Hal ini menjadi cerminan bahwa sesungguhnya permasalahan korupsi di Indonesia tidak lagi dalam persoalan penegakan hukumnya melainkan lebih pada persoalan karakter dan mental yang 
dibangun oleh masing-masin manusia Indonesia.

Oleh karena itu dalam penanggulangan dan pemberantasan tindak pidana korupsi diperlukan adanya suatu kebijakan hukum pidana yang integral dan menyeluruh sehingga akan dapat menyentuh berbagai aspek bidang kehidupan yang rentan korupsi.

Kebijakan penanggulangan kejahatan yang bersifat integral secara umum akan melibatkan berbagai aspek dan tidak semata-mata hanya menggunakan cara hukum melalui penegakan hukum pidana melainkan dengan menggunakan caracara diluar hukum yang lebih bersifat prevensi atau mencegah terjadinya kejahatan, salah satunya dengan cara memberikan pendidikan anti koruptif pada masyarakat khususnya generasi muda bangsa Indonesia.

\subsection{Kesadaran Generasi Muda Tentang Perannya Sebagai Agent of Change dalam Pencegahan Korupsi}

Generasi muda merupakan lapisan terbawah dari masyarakat yang umumnya terdiri dari anak-anak, remaja dan pemuda yang berumur antara 0 - 30 tahun. Generasi muda memiliki arti yang amat penting dalam tatanan kehidupan suatu bangsa. Sebagaimana umum diketahui, generasi muda merupakan tulang punggung suatu bangsa yang dibahunya terdapat harapan-harapan akan masa depan yang lebih baik.

Generasi muda sangat identik dengan perubahan dan bahkan kerap menjadi motor bagi perubahan itu sendiri. Di Indonesia, peran generasi muda dalam perubahan dapat ditelusuri dalam sejarah kehidupan bangsa Indonesia sendiri baik itu di era penjajahan maupun di era kemerdekaan. Ada banyak gerakangerakan pemuda yang mewarnai perjalanan sejarah Indonesia yang sebagian besar menunjukkan arah menuju perubahan. Contohnya di masa penjajahan atau sebelum kemerdekaan, ada gerakan pemuda yang menghantarkan pemuda Indonesia untuk melakukan Sumpah Pemuda yang melibatkan berbagai pemuda dari seluruh Indonesia. Kemudian di masa setelah kemerdekaan, ada beberapa gerakan pemuda seperti Angkatan 66 yang mengkritisi pemerintah Indonesia sampai gerakan pemuda pada reformasi 1998.

Uraian tersebut menggambarkan bahwa pemuda memiliki suatu potensi sebagai agen perubahan atau agent of change. Potensi agent of change ini terlihat dalam idealisme dan integritas murni dari generasi muda dalam menyikapi permasalahan-permasalahan sosial. Seringkali generasi muda memiliki pemikiran dan tindakan kritis yang dapat membawa perubahan bagi bangsa menuju ke arah yang lebih positif di masa mendatang.

Potensi agent of change menjadikan generasi muda selalu diyakini sebagai asset bangsa. Hal serupa juga diyakini oleh Abraham Samad yang melihat potensi generasi muda dalam pencegahan korupsi. ${ }^{12}$ Abraham Samad menyebutkan pemuda sebagai asset bangsa, di masa mendatang akan menduduki posisi-posisi strategis, jabatan publik dan pembuat kebijakan di masa depan. ${ }^{13}$ Ia menilai pemuda tidak hanya berperan sebagai objek pemberantasan dan pencegahan korupsi tetapi juga sebagai subjek yang dapat berkontribusi penuh. Menurutnya, pemuda dengan idealisme dan integritasnya merupakan motor penggerak perubahan. ${ }^{14}$ Oleh karenanya amatlah penting untuk menjaga idealisme dan integritas murni generasi muda agar tidak teracuni oleh politik dan kekuasaan serta hal-hal lainnya yang dapat mengguncang ketahanan generasi muda.

Sehubungan dengan itu, persoalan kesadaran generasi muda tentang perannya sebagai agen perubahan atau agent of change dalam pencegahan korupsi amatlah penting untuk ditelusuri. Dengan menyadari perannya tersebut, maka diharapkan ada keinginan untuk

\footnotetext{
${ }^{12}$ https://www.kpk.go.id/id/home-en/81berita/siaran-pers/125-bangun-generasiantikorupsi-kpk-gandeng-para-pemuda-indonesia diunggah pada tanggal 23 Agustus 2016

${ }_{13}^{13}$ ibid.

${ }^{14}$ Ibid
} 
mencegah korupsi agar tidak terjadi lagi di masa mendatang. Namun berdasarkan hasil penelitian tentang Kesadaran Hukum Mahasiswa Fakultas Hukum Universitas Udayana dalam Mengembangkan Perilaku Anti Koruptif dapat diketahui bahwa terdapat inkonsistensi antara kesiapan mahasiswa untuk berperan serta dalam pencegahan korupsi dengan kemauan untuk mengembangkan perilaku anti koruptif.

Secara deskriptif, tergambar bahwa mahasiswa sebagai generasi muda menyatakan siap untuk berperan serta dalam pencegahan korupsi namun disisi lain menyatakan ketidaksiapannya untuk mengurangi perbuatan-perbuatan yang dapat dikategorikan sebagai bibit korupsi. Mahasiswa sebagai generasi muda juga menyatakan ketidaksiapannya dalam mengembangkan perilaku anti koruptif. Deskripsi ini mengindikasikan bahwa mahasiswa sebagai generasi muda masih belum menyadari perannya sebagai agen perubahan dalam pencegahan tindak pidana korupsi. Meskipun mahasiswa sebagai generasi muda memiliki cukup pemahaman tentang peliknya permasalahan korupsi di Indonesia dan juga tentang pentingnya korupsi itu diberantas namun hal-hal tersebut belum menjadi suatu alasan bagi generasi muda untuk mengembangkan perilaku anti koruptif..

Indikator ketidaksiapan ini merupakan suatu bentuk kelemahan terhadap penanggulangan tindak pidana korupsi dari segi preventif. Generasi muda yang dalam hal ini diwakili oleh mahasiswa belum siap membawa perubahan di bidang pencegahan korupsi bagi Indonesia. Indikator ini juga menjadi suatu indikasi bahwa generasi muda belum cukup memahami perannya sebagai agent of change. Hal ini juga disebabkan karena masih lemahnya kesadaran hukum generasi muda tentang pentingnya pencegahan korupsi dan pentingnya mengembangkan perilaku anti koruptif.

Kesadaran hukum merupakan persoalan pemahaman seseorang dalam memaknai hukum. Kesadaran hukum tidak mudah diberi pengertian secara baku karena menyangkut persoalan nilai dalam diri seseorang. Kesadaran hukum seringkali berkaitan erat dengan persoalan kepatuhan seseorang terhadap hukum atau norma yang sudah ada. Kesadaran hukum dalam diri manusia kerap kali muncul dalam bentuk nilainilai positif dan negative yang difilterisasi dengan menggunakan kesusilaan dan keadilan kemudian melahirkan konsepsi abstrak tentang kepatutan yang diwujudkan dengan kepatuhan hukum.

Oleh karena itu, dalam upaya membangun kesadaran hukum seseorang, edukasi atau pendidikan merupakan salah satu jalur yang dapat dipergunakan. Dengan jalan pendidikan seseorang diharapkan dapat membangun karakter yang paham dan taat akan hukum sehingga akan memiliki kemauan untuk melaksanakan hukum dan menjadi bagian dari hukum itu sendiri.

\subsection{Pentingnya Pendidikan Anti Korupsi dalam Menumbuhkan Kesadaran Hukum Generasi Muda Untuk Berperilaku Anti Koruptif.}

Pendidikan memiliki suatu peran penting dalam pembentukan karakter daripada suatu bangsa. Melalui pendidikan seringkali muncul harapanharapan tentang kesejahteraan di berbagai bidang.

Secara terminology, pendidikan berasal dari kata paideia (pedagogi), artinya pembentukan generasi muda agar menjadi manusia yang berbudaya dan mampu mengambil bagian dalam kehidupan di tengah masyarakat. Pendidikan sebagaimana diungkapkan oleh Ki Hajar Dewantara memiliki tujuan untuk menumbuhkan peserta didik menjadi manusia yang luhur akal budinya. ${ }^{15}$ Pendidikan yang berbudi luhur adalah pendidikan yang ingin mengantar

\section{${ }^{15}$ Donny Gahral Adian dkk, 2002,} Pendidikan Memang Multikultural Beberapa Gagasan, Editor Aryo Danusiri dan Wasmi Alhaziri, Yayasan Sains Estetika dan Teknologi (SET), Jakarta, hlm. 136 
peserta didik menjadi generasi muda yang memiliki keutamaan moral bijaksana, tangguh, adil, ugahari. Dan memiliki keutamaan teologial: iman, harapan dan kasih. ${ }^{16}$ Dengan demikian dapat dikatakan bahwa pendidikan merupakan salah satu sarana ideal dalam menumbuhkembangkan karakter seseorang agar lebih berbudaya dan bermartabat sebagai manusia.

Dalam kaitannya dengan pencegahan korupsi, maka pembentukan karakter haruslah menjadi dasar utama pendidikan anti koruptif. Tanpa adanya dasar utama pembentukan karakter maka tujuan dilaksanakannya pendidikan anti koruptif pun akan menjadi sia-sia. Pendidikan anti koruptif tidak dirancang untuk memberantas korupsi tanpi mencegah dengan jalan melatih orang untuk memiliki kesadaran untuk berperilaku anti koruptif. Pendidikan anti koruptif tidak akan memiliki daya guna jika karakter yang terbentuk masih bukan karakter anti koruptif. Oleh karena itu dalam pendidikan anti koruptif, pemahaman tentang nilai-nilai korupsi sebagai nilai-nilai yang negative dan merugikan banyak pihak sangatlah penting diberikan. Dengan pemahaman demikian maka akan terbentuk karakter anti koruptif.

Pembentukan karakter anti koruptif yang dilakukan melalui pendidikan anti koruptif akan mempertajam dan mengasah idealisme dan integritas yang dimiliki oleh generasi muda dalam memandang korupsi sebagai perbuatan melawan hukum yang harus segera dicegah, ditanggulangi dan diberantas karena dapat mengakibatkan kerugian yang sifatnya materiil maupun immateriil.

Pendidikan anti koruptif dengan mengembangkan pembentukan karakter anti koruptif pada prinsipnya mendapat tantangan besar dari kondisi korupsi yang saat ini sudah begitu membudaya dan mengakar daging namun pembentukan karakter anti koruptif ini harus terus menerus diupayakan sebagai bentuk penanggulangan korupsi di masa mendatang. Dengan membentuk kembali karakter anti koruptif pada generasi muda maka akan mengembalikan nilai-nilai anti koruptif sehingga dapat membantu upaya pencegahan tindak pidana korupsi di masa mendatang.

Berkaitan dengan pentingnya pendidikan anti koruptif, KPK sebagai lembaga yang ditugaskan dalam hal penanggulangan korupsi memberikan respon positif dengan berperan aktif mengembangkan edukasi-edukasi anti koruptif. Misalnya melalui laman www.acch.kpk.go.id KPK telah menyediakan ragam edukasi anti koruptif bagi setiap masyarakat dengan menyediakan bacaan-bacaan, metode games dan audio visual untuk lebih memudahkan setiap masyarakat mempelajari nilai-nilai anti koruptif. Di laman tersebut setiap masyarakat dapat mengakses kebutuhan pengetahuannya melalui fitur-fitur pilihan edukasi.

Dalam hal ini nampak terlihat usaha KPK untuk menyentuh generasi muda yang melek teknologi (generasi milenial) untuk belajar secara aktif tentang korupsi dan nilai-nilai anti koruptif. KPK menyakini bahwa korupsi harus ditanggulangi secara integral dan menyeluruh, tidak hanya terbatas pada penegakan hukum semata melainkan membentuk karakter anti koruptif melalui dunia pendidikan.

\section{PENUTUP}

\subsection{Kesimpulan}

Berdasarkan uraian-uraian singkat tersebut diatas, dapat dirumuskan kesimpulan sebagai berikut:

1. Korupsi merupakan masalah krusial di Indonesia, hal ini tergambar dalam statistik yang dikeluarkan KPK tentang tindak pidana korupsi dari tahun 2004 hingga 2017. Tindak pidana korupsi tidak pernah ada pada titik nol selalu ada dan mengancam kehidupan bangsa Indonesia.

2. Berdasarkan hasil penelitian yang telah dilakukan dijumpai suatu keadaan dimana generasi muda masih apatis dalam menyikapi korupsi. Di 
satu sisi, generasi muda menyadari bahwa korupsi di Indonesia sudah sangat kritis dan juga menyadari bahwa korupsi merupakan suatu perbuatan yang melawan hukum serta merugikan. Di sisi lain, generasi muda menyatakan belum siap jika harus mengembangkan perilaku anti koruptif seperti tidak mencontek, tidak datang terlambat, tidak menggelapkan uang orangtua dan lain sebagainya. Dalam situasi seperti ini, artinya generasi muda belum memiliki kesadaran akan perannya sebagai agen perubahan bagi bangsa ini dibidang korupsi.

3. Untuk mengatasi permasalahan kesadaran hukum generasi muda, pendidikan anti koruptif merupakan salah satu solusi yang dapat diberikan. Pendidikan anti koruptif harus ditujukan untuk membentuk kembali karakter dan mental anti koruptif dari dalam diri sendiri untuk selanjutnya ditularkan kepada lingkungannya. Dengan ditujukan kembali pada pembentukan karakter anti koruptif diharapkan akan melahirkan dan meningkatkan nilai-nilai anti koruptif serta membudayakan kembali nilainilai tersebut ke tengah-tengah masyarakat. Harapannya korupsi akan tercegah karena banyaknya masyarakat yang menyadari bahwa korupsi adalah perbuatan tercela dan merugikan.

\subsection{Saran}

Ada pun saran yang dapat diberikan adalah :

1. Berkaitan dengan pelaksanaan pendidikan anti koruptif itu sendiri dimana pendidikan ini seyogyanya dapat diberikan kepada generasi muda sejak usia dini. Dengan demikian, upaya pembentukan karakter anti koruptif sudah dimulai sejak generasi muda berada ditahap usia termuda.

2. Perlu diusulkan adanya kebijakan pencegahan anti korupsi dengan mengembangkan pendidikan anti koruptif sebagai salah satu bagian kurikulum pendidikan di Indonesia.

\section{DAFTAR PUSTAKA}

Donny Gahral Adian dkk, 2002, Pendidikan Memang Multikultural: Beberapa Gagasan, Editor Aryo Danusiri dan Wahmi Alhaziri, Yayasan Sains Estetika dan Teknologi (SET), Jakarta

H. Elwi Daniel, 2011, Korupsi: Konsep, Tindak Pidana dan Pemberantasannya, Rajawali Pers, Jakarta

Ikhwan Fahrojih, 2016, Hukum Acara Pidana Korupsi, Setara Press, Malang

I Gusti Agung Ayu Dike Widhiyaastuti dkk, 2016, Klinik Hukum Anti Korupsi Edukasi Pencegahan Melalui Street Law, Udayana University Press, Denpasar Bali

Mahrus Ali, 2016, Hukum Pidana Korupsi, UII Press, Yogyakarta

https://ugm.ac.id/id/berita/433-sejarawan. ugm. korupsi. warisan. dari. penyakit. sosial.orang.indonesia

http://sejarah.kompasiana.com/2012/06/22/korupsi-birokrasi-sebuahwarisan kolonial-471739.html

https://acch.kpk.go.id/id/statistik/tindak-pidana-korupsi/tpk-berdasarkanjenis-perkara

https://www.kpk.go.id/id/home-en/81-berita/siaran-pers/125-bangun-generasiantikorupsi-kpk-gandeng-para-pemuda-indonesia 